\title{
CONDITIONS AND TRIGGERS OF LANDSLIDES ON FLYSCH SLOPES IN ISTRIA, CROATIA
}

\author{
Sanja Dugonjić Jovančević ${ }^{1 *}$ - Josip Rubinić ${ }^{1}$ - Željko Arbanas ${ }^{1}$ \\ ${ }^{1}$ Department of Hydrotechnics and Geotechnics, Faculty of Civil Engineering, University of Rijeka, Radmile Matejčić \\ 3, Rijeka, Croatia
}

\begin{tabular}{l} 
ARTICLE INFO \\
\hline Article history: \\
Received: 14. 12. 2018. \\
Received in revised form: 12. 2. 2019. \\
Accepted: 25. 2. 2019. \\
\hline Keywords: \\
Landslide \\
Cumulative rainfall amount \\
Trigger \\
Flysch \\
Gray Istria \\
\hline DOI: http://doi.org/10.30765/er.40.2.09
\end{tabular}

\section{Introduction}

Landslide hazard and risk assessment, together with the responsibility for future catastrophe reduction, are highly significant in urban planning and land use management, in every part of the world. Existing developed methodologies can be used in the framework of landslide hazard assessment and risk management [1], but in many parts of the world,

\begin{abstract}
:
The paper gives a review of conditions and triggers in which landslides occur on flysch slopes in central and northern Istria. The north-eastern part of the Istrian Peninsula, the so-called Gray Istria, consists of Paleogene flysch rock mass. Landslides in this area are usually triggered by heavy rainfall together with human activity which changes slope geometry and assists in retaining surface water in the sliding zone. Briefly, hydrogeological conditions in combination with ground water levels and pore water pressures increase, lead to numerous instability phenomena, during the long and continuous rainfall periods. Instabilities usually include small rotational and translational landslides, and it is seldom that debris flows and rock falls occur. Landslides are evenly evidenced in the first part of winter and the early spring time which corresponds to the second rainfall peak. The analyses performed based on landslide documentation and rainfall historical data, show rainfall trends associated with landslide occurrence. Depending on meteorological, hydrological and geological conditions, cumulative rainfall which triggered landslide activation varies inside a three-month period. The results presented show rainfall trends which serve as characteristic landslide triggers on flysch slopes in north-eastern part of Istria.
\end{abstract}

adopted methods are still in the initial stage of usage. Alike, numerous analysis show only results of the spatial landslide distribution (i.e., landslide susceptibility), however no expected frequency of such events (return periods as temporal component of landslide hazard analysis). Aiming to get this information, analysis of landslide triggers (rainfall, earthquake, snow melt, human activity, etc.) should be performed. Landslide hazard assessment is

\footnotetext{
* Corresponding author. Tel.: +385 51265 934; fax: +385 51265998

E-mail address: sanja.dugonjic@uniri.hr
} 
generally not performed in Croatia, as opposed to several regionally performed landslide susceptibility zoning, mostly as qualitative geomorphologic analysis for the purpose of urban planning. The largest total area included in the susceptibility zoning covers $175 \mathrm{~km}^{2}$ [2].

The research area, covering $550 \mathrm{~km}^{2}$, is located on the slopes in north-eastern Istria, called the Gray Istria, formed in Paleogene flysch rock, where the appearance of small landslides, triggered almost exclusively by long and continuous precipitation, is frequent. Major damage and landslide consequences are evidenced on local roads, and, rarely, other structures and facilities.

The term flysch has been introduced in the geological literature by the Swiss geologist Bernhard Studer [3], who used the term for the typical alternations of sandstone and shale in the foreland of the Alps. It presents a complex of clastic sedimentary rocks originating from the muddy flows and submarine sliding of deposits [4], known as submissive to weathering and significant change of physical-mechanical properties in short time. For more detail description of the mentioned sedimentology rocks and understanding of these formations, several important researches can be recommended: [5-11], while problems of sliding in flysch deposits at the Istrian Peninsula are described in [12-22]. The area of north-eastern Istria has a lithological composition and structural-tectonic fabric, which differ from other areas of the large flysch pool spreading from Gorizia (Italy) all the way to Albania [23]. However, existing geological conditions, as well as geomorphological and physical processes on the flysch slopes in the Gray Istria, generally present conditions for landslide appearance and rock falls, and rarely debris flows.

Landslides are usually triggered by heavy rainfall, and some aided by human activity that significantly changes the slope geometry [17], while other factors, such as snow melting and earthquakes, are not significant as triggers because of climate conditions and low seismic activity of the area (Table 1). Direct trigger is infiltration of the rainfall in the cover, mostly built of clay and mud particles, and deposits of different weathering grade, to the almost impermeable fresh flysch bedrock. Raising of the groundwater level and pore pressures, causes decrease of effective stresses and decrease of the shear strength, what gradually leads to sliding. Dugonjić Jovančević and Arbanas have shown that the cumulative twelve-month values, as well as the maximum monthly, weekly or daily precipitation which preceded sliding, do not have significant influence on landslide initiation. Their analyses evidence that the amounts of approximately threemonth precipitation (70-100 days) which triggered past landslides vary from around 450 to $700 \mathrm{~mm}$ [17]. The period of 3-month cumulative precipitation that caused landslide initiation on the flysch slopes in Gray Istria is longer than the periods in other countries that have similar flysch geological settings (25 to 45 days in the Polish Flysch Carpathians [24]; 15 to 60 days in the Northern Apennines in Italy [25]; 30 to 60 days in the Southern Apennines in Italy [26]; 25 days in the Slano Blato Landslide in Slovenia [27]; and "several months" in the Outer Western Carpathians in the Czech Republic [28]. Rainfall infiltration through initially unsaturated residual soil can be simulated as a transient process in order to investigate the influence of different initial conditions (moisture contents) of the geotechnical cross-section and rainfall characteristics on the pore water pressure changes and, consequently, changes in slope stability state in time [21]. Table 1. General landslide data in the research
area

\begin{tabular}{ll} 
Landslide data & Number/amount \\
\hline Landslide prone area & $550 \mathrm{~km}^{2}$ \\
Estimated landslide volume & $700 \mathrm{~m}^{3}-176.000 \mathrm{~m}^{3}$ \\
Documented landslides & 22 \\
Triggered by rainfall & 22 \\
Influenced by human activity & 8 \\
Rotational sliding & 15 \\
Translational sliding & 4 \\
Debris flow & 1 \\
Rock fall & 2 \\
Rainfall trigger (three-month & $450-700 \mathrm{~mm}$ \\
cumulative amount) & \\
Average twelve-month & $\approx 1200 \mathrm{~mm}$ \\
precipitation & \\
\hline
\end{tabular}

This paper presents an insight into the analysis of triggering factors, as well as the calculation of the return periods of expected landslide appearances, similar to the past events. Data from two rain gauges were analyzed in relation to three landslide occurrences in order to determine the frequency of similar rainfall patterns. The maximum daily rainfall and the number of continuous rainy days during the considered period were analyzed. The results show 
the expected trends of the temporal component of the landslide hazard in this area.

\section{Features influencing landslide appearance}

The Pazin Paleogene Flysch Basin or Gray Istria stretches from Trieste Bay in the west to Učka Mountain in the east (Fig. 1). The south-western border of this area is Red Istria, formed of Jurassic limestone, sporadically covered by the so-called terra rossa (engl. red Mediterranean soil), and the north-eastern border is on the contact with the Ćićarija Mountain range, which forms the White Istria built in Cretaceous limestone [29].

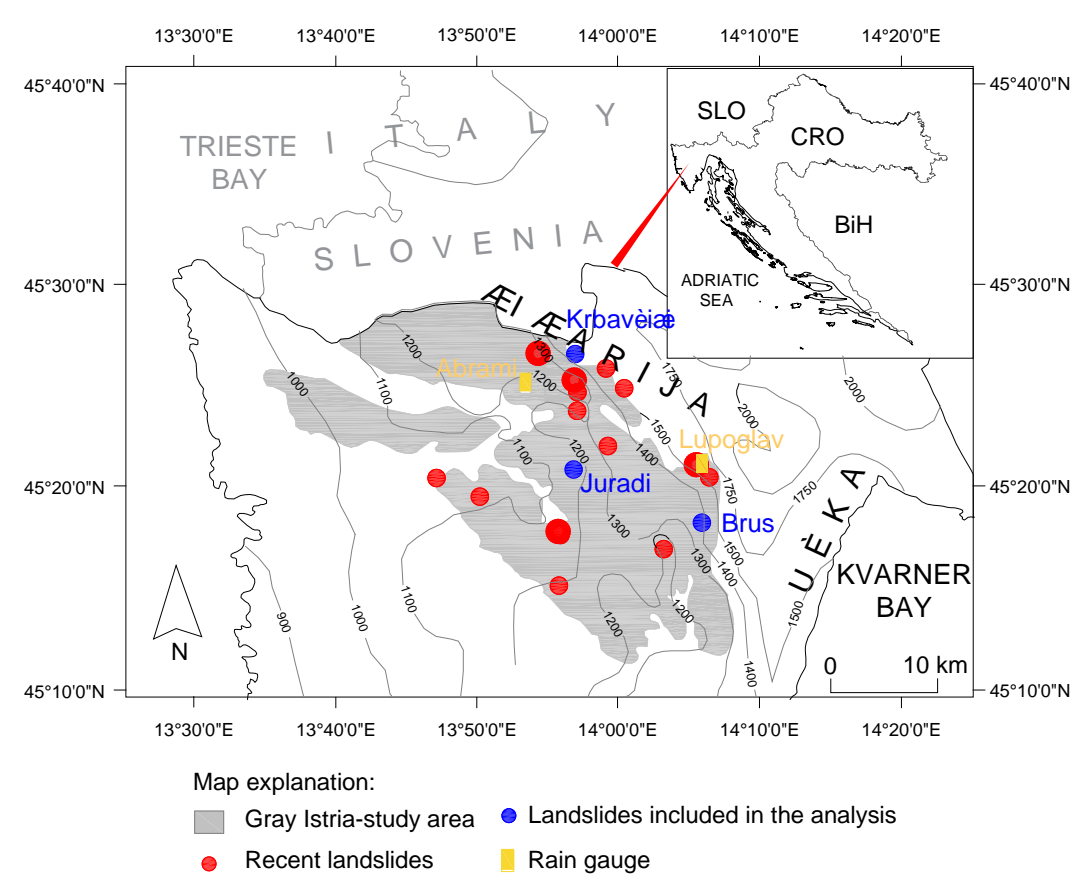

Figure 1. Annual rainfall amounts in the central and northern part of the Istrian Peninsula (modified according to the data from Croatian Meteorological and Hydrological Service in 2011)

The central Istrian flysch rock mass is a part of the large flysch basin, covering the area from Gorizia in Italy to Albania [23] (Fig. 2). This basin has been formed during the Pyrenean orogeny, at the end of the Paleogene period. Tectonic movements from this and later geological periods, have caused folding and faulting of NW-SE structures. The final shape of the geological structures has been formed through the tectonic reactivation, along the reverse faults from the upper Pliocene to now days [30]. The consequence of these tectonic movements was sporadic extreme squeezing of the flysch sedimentary basin in the Adriatic zone and reduced rock outcrops visible on the surface [29].

Foraminifera limestone are forming the shelf of the characteristic geological column, while the siliciclastic rocks with characteristics of flysch rock mass are formed on top. The bottom part of the flysch series is mostly homogeneous marl. The flysch rock mass in the upper series is lithologically heterogeneous and consists of clay and siltstone with layers of calcified sandstone and brecciaconglomerate (Fig. 3). The flysch rock mass was significantly deformed except for the contact with Ćićarija mountain range in the north-east and Učka mountain in the east. The layers have almost horizontal orientation [31-35]. The research area is sporadically covered with thick layers of potentially unstable talus deposits and colluvium consisting of weathered flysch rock mass mixed with granular fragments of carbonate rock transported from higher slopes.

As mentioned before, the flysch rock mass exposed to atmospheric influences degrades with respect to its mechanical properties in a short period. Mechanical weathering accelerates the chemical weathering, characteristic for the flysch rock mass. Weathered flysch is prone to erosion and sliding 
inside extremely unstable accumulations of eroded deposits. Landslides in the flysch slopes occur in two typical forms: (i) deep-seated landslides through the flysch rock mass (some parts of the slip surface could cut through the superficial colluvial deposits) and (ii) shallow landslides with slip surfaces at the contact of the superficial deposits and flysch rock mass or through the superficial colluvial deposits [21]. A typical mechanism of mass movements in the area of Gray Istria is sliding of the cover, with properties of the engineering soil and flysch rock mass of different weathering grade over the fresh flysch bedrock. Krbavčići, Brus and Juradi landslide (Fig. 1), as typical landslides in this area, have been considered in the trigger analysis. The Krbavčići landslide occurred during the night between January 30 and 31 of 1979, as multiple retrogressive sliding, after a prolonged rainy period from October 1978 through January 1979. 10 m thick clayey superficial deposit and road embankment slid over the flysch bedrock $200 \mathrm{~m}$ down the slope and $176.000 \mathrm{~m}^{3}$ of material buried a vineyard at the landslide toe. The Brus landslide started with open cracks positioned on the main scarp in December 2004, and ended as translational almost-undisturbed flysch block sliding, on April 9, 2005, including $35.000 \mathrm{~m}^{3}$ of landslide body. The sliding was caused by the unfavorable orientation of the layers, while intensive continuous rainfall was the trigger. According to the village inhabitants, movements at the Juradi landslide have been repeatedly occurring for the last 80 years, and the last reactivation, analyzed in this paper, occurred on December 1, 2010 including approximately $47,000 \mathrm{~m}^{3}$ of the sliding material. The surface of rupture was positioned on the contact between the 5-to-14-m thick cover deposit and the siltstone bedrock layers.
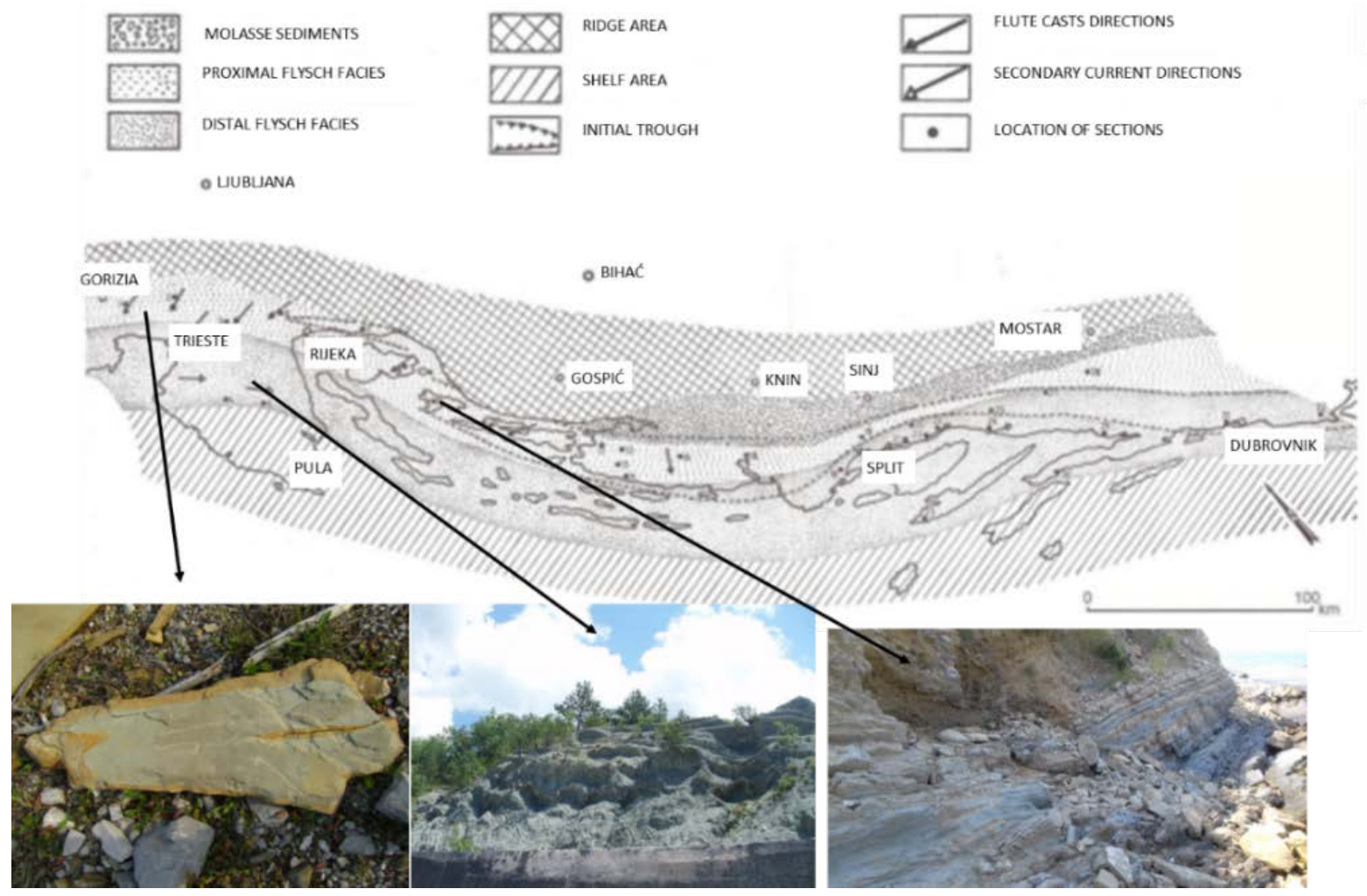

Figure 2. Distribution of flysch facies with examples of the rock in the surrounding area (according to [23])

The hydrography and the hydrology of the Istrian Peninsula are conditioned by the geological fabric, repeated tectonic movements and faulting during the Quaternary period. As a result of these processes, the flysch rock mass is significantly deformed on the flysch-karst contact, and water flows mostly sink and continue their flow underground, while just a few continue their surface flow. Because of the greater altitude, the temperature is lower and the precipitation amounts are higher $(>1500 \mathrm{~mm})$ in the areas of Ćićarija and Učka Mountain range than in other parts of the peninsula. Minimal rainfall amounts are present on the western and southwestern coast (Fig. 1). Although precipitation 
amounts increase from west to east, the entire peninsula has a similar rainfall regime. As shown on Fig. 4a, most rainfall occurs in the autumn (November is the rainiest month with an average rainfall amount $>160 \mathrm{~mm}$ inside the measured period 1961-2010), and the secondary peak appears in the period from spring to summer, with no expressed arid periods through the year. Maximum daily rainfall amounts on several rain gauges are shown in Fig. 4b, where it can be seen, that the highest recorded daily rainfall exceeded $160 \mathrm{~mm}$ and an average daily amount during this period is $87 \mathrm{~mm}$.

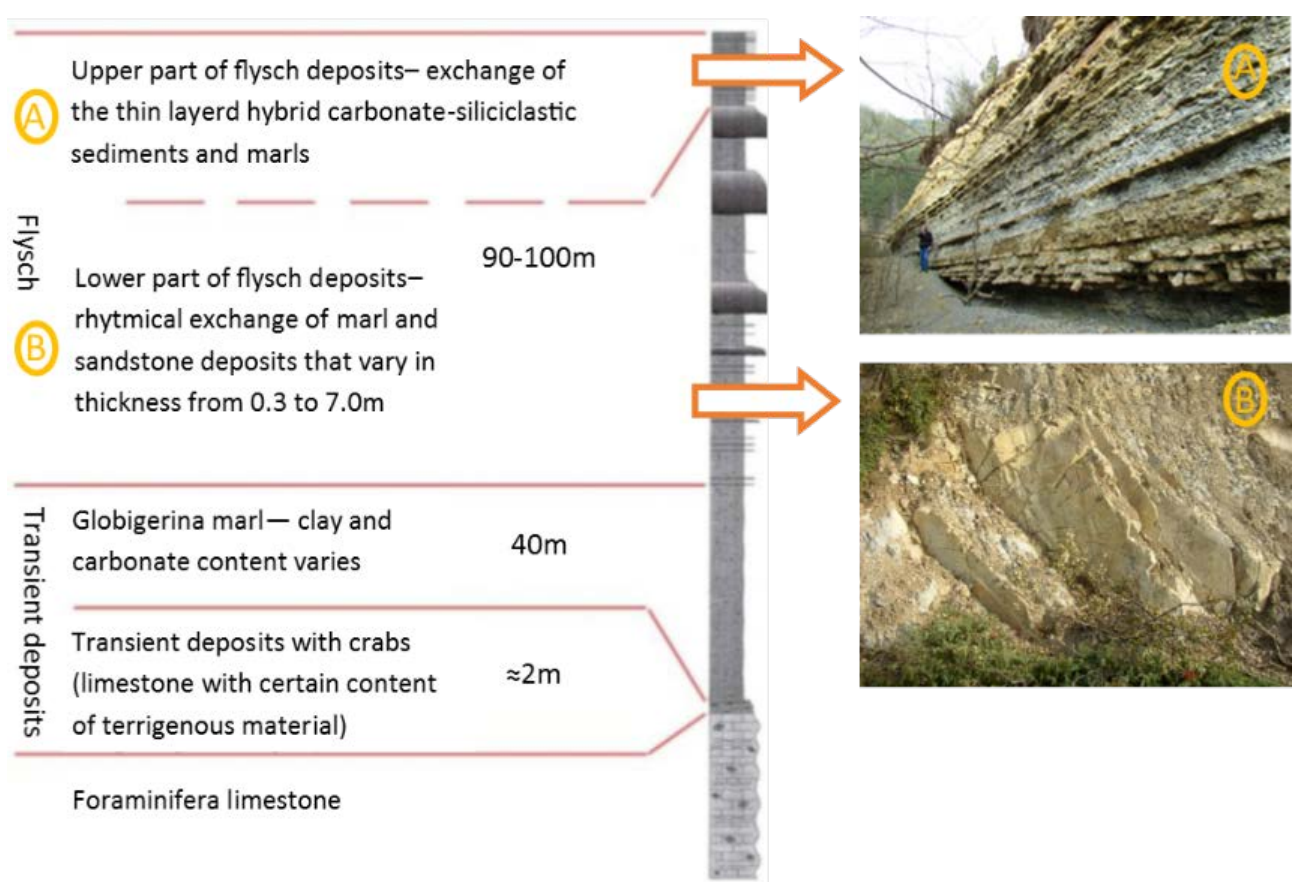

Figure 3. Geological column of siliciclastic Paleogene deposits in the Gray Istria (modified according to [36])

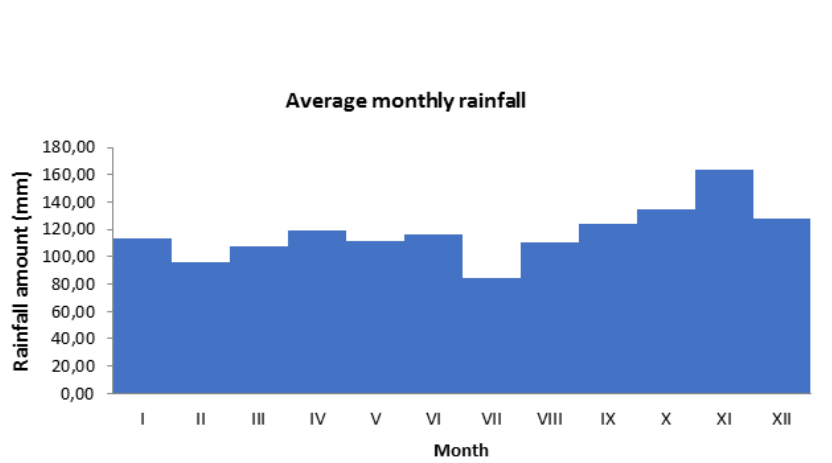

a)

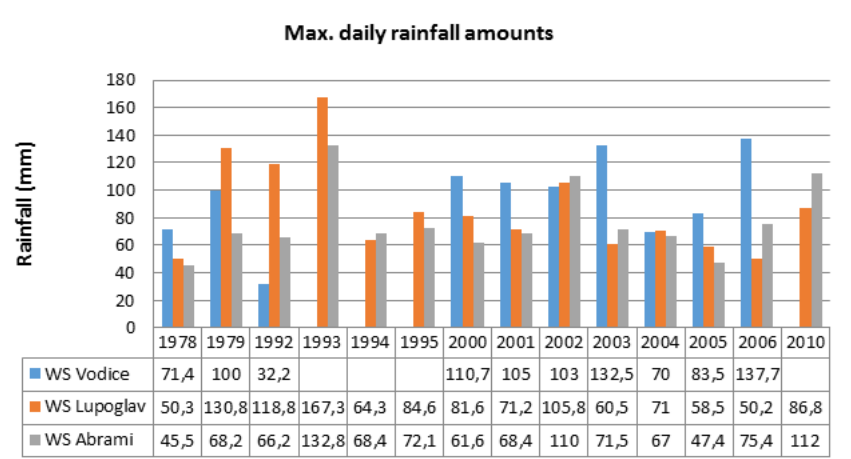

b)

Figure 4. Rainfall trends in the research area: a) average monthly rainfall, b) maximum daily rainfall

\section{The analysis of the rainfall triggers}

\subsection{Methodology}

The research methodology can be divided in several phases: (i) rainfall data collection, (ii) data processing, (iii) analysis of landslides with known date of appearance and antecedent rainfall, (iv) analysis of the rainfall return periods, (v) overall evaluation of the results. Data were gathered from the Croatian Meteorological and Hydrological Service (DHMZ), archive of the Geotechnical department at the Faculty of Civil Engineering, University of Rijeka, Istrian County Roads Office and the Civil Engineering Institute of Croatia 
archives. They included the rainfall amounts, geological and geotechnical data from geotechnical field studies for remediation works on landslides in the research area. The rainfall amounts used in determination of the temporal landslide hazard component included data about daily, monthly and annual amounts in the period from 1961 to 2010 on six rain gauges (RG). Three-month cumulative rainfall events exceeding the critical, triggering, rainfall amounts and duration, were related to three referent values which triggered landslides Krbavčići, Brus and Juradi, described in the previous chapter. The exact time of sliding was accepted from the existing documentation, and the hypothesis was that future slope movements will appear in conditions similar to the ones antecedent to past landslides.

In order to determine the return periods, respectively the frequency of the critical amount of rainfall which triggered landslides in the past, all threemonth cumulative rainfall amounts in the measuring period were analyzed. Data from two rain gauges Lupoglav (right RG in Fig. 1), and Abrami (left RG in Fig. 1) were considered as representative and had the acquired measurement records for this analysis. Although annual rainfall amounts shown in Fig 1 indicate relatively large differences on relatively small distances, these differences reduce when considering average annual amounts in the total measuring period (RG Lupoglav has the average annual rainfall $1290 \mathrm{~mm}$ and RG Abrami $1150 \mathrm{~mm}$ from 1961-2010). The number of rainy days which preceded sliding was analyzed in order to determine the precipitation continuity. Events which included some arid days were not eliminated from the analysis, and were taken into account as continuous rainy periods. The probability of three-month critical cumulative rainfall appearance was calculated using two-parameter Gamma function, as generally most adaptive to series of input data, according to conducted Smirnov-Kolmogorov test $[37,38]$ and $\chi^{2}$-test.

\subsection{Results}

Table 2 and Fig. 5 show cumulative rainfall values, number of rainy days and the maximum daily rainfall in the three-month period preceding a landslide event, related to three landslide occurrences.

Although a large number of events with high threemonth cumulative values was registered before
1971, there were no precipitation records before 1978. Therefore, landslide appearance was in several cases correlated with the RG Abrami that has records of daily rainfall amounts for the year in which sliding occurred (in Table 1 marked with „*“). The absence of daily rainfall records, on each of the six rain gauges, was evidenced and marked as „-“ in Table 2 and can be seen as zero rainy days in Fig 5.

The analysis has shown that maximum daily precipitation does not have a significant influence on landslide initiation. Figure 5 shows that the number of rainy days for each critical event related to three landslides, varies from 24 to 56 inside the three-month period. However, it can be noticed that the number of rainy days which preceded landslide appearance inside the three-month is larger or equal to $1 / 3$ of the number of days in the period.

There were 10 more events in 49 years, which exceeded the critical three-month rainfall amount, that triggered the Krbavčići landslide in February 1979 (548.1 mm of continuous cumulative rainfall). The cumulative precipitation amount which triggered the Brus landslide that occurred in December 2005 was $582.7 \mathrm{~mm}$. Events related to the Brus landslide show, that in average, every second year there is one three-month rainfall amount exceeding the triggering value recorded in 2005 (25 events in 50 years). Taking a closer look, it can be seen, that these events mostly appear in successive months of the same year (three or more in the same year and season), while there are some years with no such event. In 2005 this was the only high threemonth cumulative value recorded, but it can also be noticed that October, November and December are critical months. The cumulative three-month rainfall amount which triggered the Juradi landslide in 2010 was $709.3 \mathrm{~mm}$. There were 6 more such events recorded in 50 years, and they all occurred before 2010 (in 1964, 1965 and 1977). The triggering values for the three landslides are marked in red in Fig. 5. It can be seen that all critical cumulativeevents exceed $500 \mathrm{~mm}$ of cumulative rainfall.

The probability of annual appearance of the threemonth rainfall greater than the critical values, which triggered the Krbavčići, Brus and Juradi landslides, shows similar rainfall trends on two rain gauges (Table 3). 
Table 2. Recorded three-month cumulative rainfall amounts exceeding the critical amount of rainfall which triggered the Krbavčicii, Brus and Juradi landslides [16]

\begin{tabular}{|c|c|c|c|c|c|c|}
\hline \multicolumn{4}{|c|}{ Event } & \multicolumn{3}{|c|}{ Rainfall trends in the three-month period } \\
\hline Related landslide & Year/Month & RG & $\begin{array}{l}\text { Critical cumulative } \\
\text { rainfall trigger }(\mathrm{mm})\end{array}$ & $\sum$ rainfall $(\mathrm{mm})$ & $\begin{array}{l}\text { Rainy } \\
\text { days' } \\
\text { number }\end{array}$ & $\begin{array}{l}\text { Max. daily } \\
\text { rainfall (mm) }\end{array}$ \\
\hline \multirow{11}{*}{ 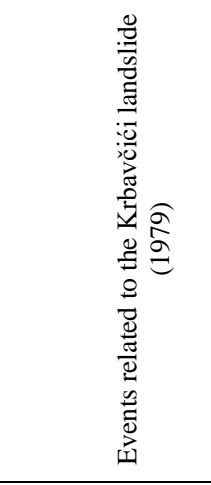 } & $1966 / 12$ & \multirow{11}{*}{ 范 } & \multirow{11}{*}{ 离 } & 549.8 & - & - \\
\hline & $1977 / 02$ & & & 562.8 & 56 & 45.6 \\
\hline & $1979 / 02$ & & & 548.2 & 45 & 46 \\
\hline & $1979 / 03$ & & & 616.4 & 48 & 46.8 \\
\hline & $1980 / 12$ & & & 580.6 & 40 & 70.3 \\
\hline & $1993 / 10$ & & & 558.6 & 39 & 132.8 \\
\hline & $1993 / 11$ & & & 657.5 & 46 & 132.8 \\
\hline & $1993 / 12$ & & & 581.1 & 46 & 132.8 \\
\hline & $2000 / 11$ & & & 586.6 & 49 & 61.6 \\
\hline & $2000 / 12$ & & & 671.3 & 51 & 61.6 \\
\hline & $2001 / 01$ & & & 693.8 & 54 & 61.6 \\
\hline \multirow{25}{*}{ 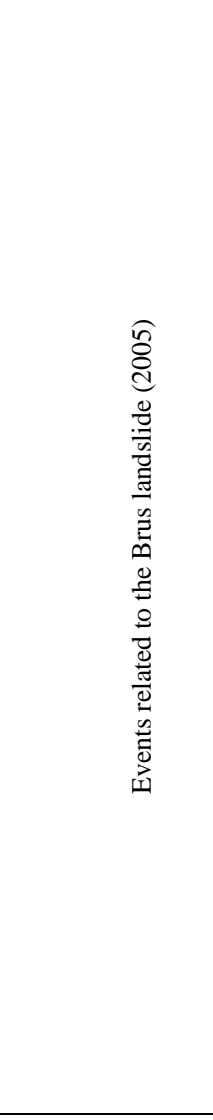 } & $1964 / 10$ & \multirow{32}{*}{$\begin{array}{l}\frac{\mathbb{t}}{00} \\
0 \\
0 \\
0\end{array}$} & \multirow{25}{*}{ 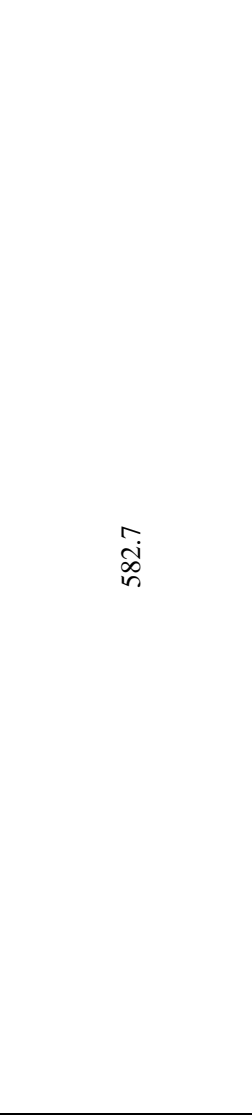 } & 805.2 & - & - \\
\hline & $1964 / 11$ & & & 760.3 & - & - \\
\hline & $1964 / 12$ & & & 824.9 & - & - \\
\hline & $1965 / 01$ & & & 648 & - & - \\
\hline & $1965 / 02$ & & & 610.7 & - & - \\
\hline & $1965 / 09$ & & & 725.8 & - & - \\
\hline & $1965 / 10$ & & & 624.5 & - & - \\
\hline & $1965 / 11$ & & & 769.7 & - & - \\
\hline & $1966 / 12$ & & & 615.3 & - & - \\
\hline & $1972 / 09$ & & & 628.8 & $35 *$ & $78.2 *$ \\
\hline & $1972 / 11$ & & & 586.7 & $30 *$ & $38.1^{*}$ \\
\hline & $1977 / 01$ & & & 664.7 & $52 *$ & $45.6^{*}$ \\
\hline & $1977 / 02$ & & & 742.7 & $56^{*}$ & $45.6^{*}$ \\
\hline & $1979 / 02$ & & & 653.8 & 46 & 60.5 \\
\hline & $1979 / 03$ & & & 701.9 & 49 & 60.5 \\
\hline & $1979 / 11$ & & & 587.9 & 24 & 130.8 \\
\hline & $1982 / 12$ & & & 627.9 & $44^{*}$ & $46.7 *$ \\
\hline & $1984 / 11$ & & & 586.6 & $39 *$ & $34.5^{*}$ \\
\hline & 1990/11 & & & 638.8 & $41^{*}$ & $52.6^{*}$ \\
\hline & $2005 / 12$ & & & 582.8 & 37 & 51 \\
\hline & $2009 / 02$ & & & 604.9 & 38 & 85.3 \\
\hline & $2010 / 01$ & & & 651 & 36 & 97 \\
\hline & $2010 / 02$ & & & 671.2 & 39 & 97 \\
\hline & $2010 / 11$ & & & 709.4 & 42 & 86.8 \\
\hline & $2010 / 12$ & & & 615.1 & 45 & 52.5 \\
\hline \multirow{7}{*}{ 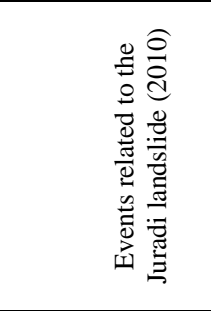 } & $1964 / 10$ & & \multirow{7}{*}{ 弚 } & 805.2 & - & - \\
\hline & $1964 / 11$ & & & 760.3 & - & - \\
\hline & $1964 / 12$ & & & 824.9 & - & - \\
\hline & $1965 / 09$ & & & 725.8 & - & - \\
\hline & $1965 / 11$ & & & 769.7 & - & - \\
\hline & $1977 / 02$ & & & 742.7 & $56^{*}$ & $45.6^{*}$ \\
\hline & $2010 / 11$ & & & 709.4 & 42 & 86.8 \\
\hline
\end{tabular}


Table 3. Annual probability of cumulative threemonth value greater than critical [16]

\begin{tabular}{lllll}
$\begin{array}{l}\text { Probability } \\
(\%)\end{array}$ & $\begin{array}{l}\text { Return } \\
\text { period } \\
\text { (year) }\end{array}$ & $\begin{array}{l}\text { Abrami } \\
(>548.2 \\
\mathrm{mm})\end{array}$ & $\begin{array}{l}\text { Lupoglav } \\
(>582.7 \\
\mathrm{mm})\end{array}$ & $\begin{array}{l}\text { Lupoglav } \\
(>709.3 \\
\mathrm{mm})\end{array}$ \\
\hline 1 & 100 & 3.1 & 5.2 & 2.7 \\
2 & 50 & 2.3 & 4 & 1.8 \\
5 & 20 & 1.3 & 2.4 & 0.8 \\
10 & 10 & 0.7 & 1.4 & 0.3 \\
20 & 5 & 0.2 & 0.6 & 0.05 \\
50 & 2 & 0 & 0.04 & 0 \\
99.99 & 1 & 0 & 0 & 0 \\
\hline
\end{tabular}

In the case of the Krbavčići landslide (1979), the amount of critical cumulative rainfall that was recorded is three times what is close to 100 -year return period. The critical cumulative rainfall related to the Brus landslide trigger, on RG Lupoglav, was recorded five times in 1965 and is also close to 100 year return period. RG Lupoglav was taken as authoritative for the analysis of the Juradi landslide trigger, and has recorded three critical cumulative rainfall amounts in 1964, what are greater than the 100 -year return period. The analysis has shown that the occurrence of the three-month rainfall event $>550 \mathrm{~mm}$, is similar to the nearly 15 -year return period in the area of RG Abrami. In the area of RG Lupoglav, the three-month rainfall event $>580 \mathrm{~mm}$ has the character of nearly 7 -year return period, while the three-month rainfall event $>700 \mathrm{~mm}$ has nearly the 25-year return period.

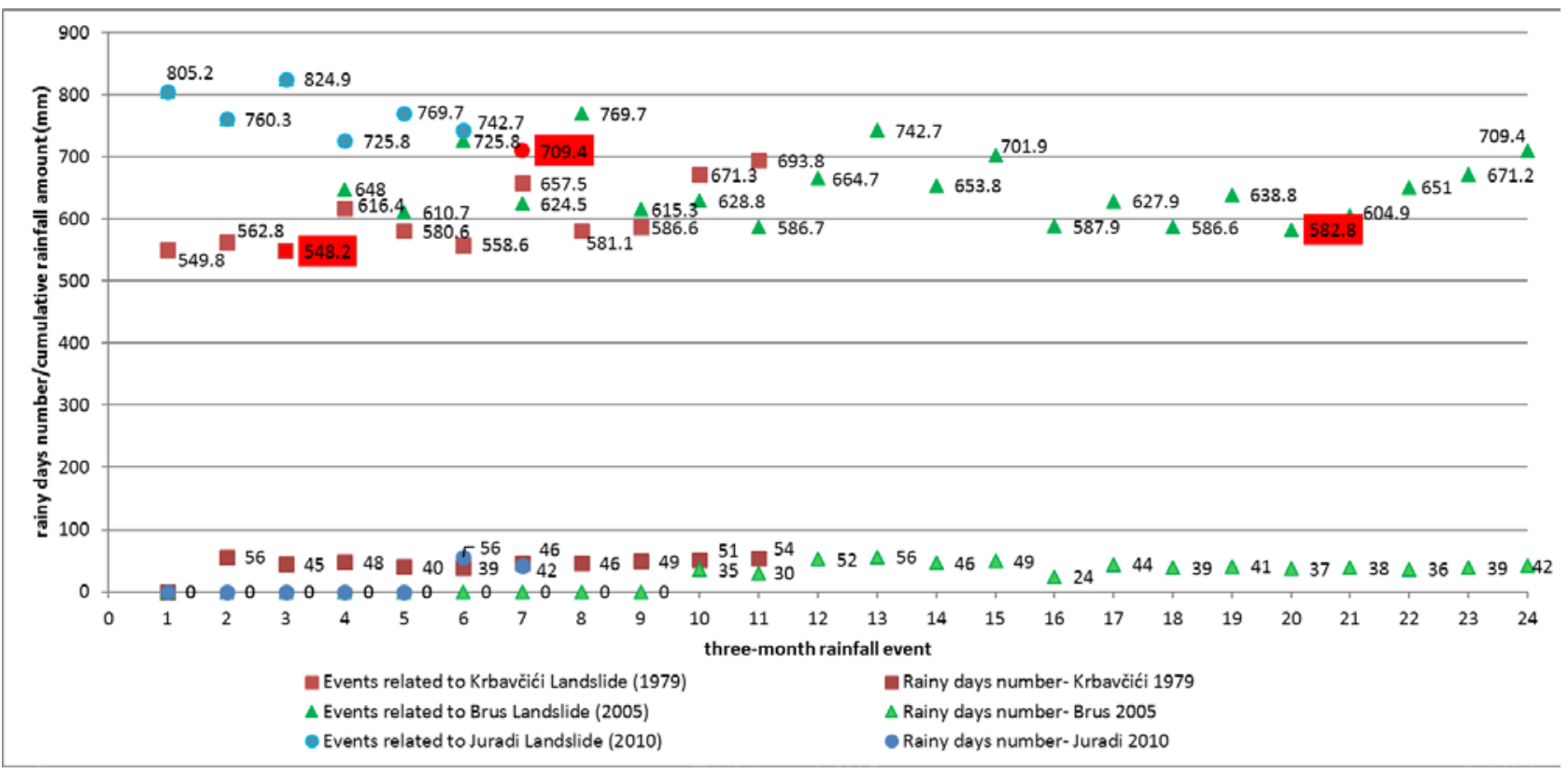

Figure 5. Trends of the three-month cumulative rainfall events related to triggering values of past landslides

\section{Conclusions}

Several case studies in the central and north-eastern Istria show that landslides typically occur as sliding of the clayey talus cover over the Paleogene flysch bedrock. They are caused by unfavorable geological settings and hydrological conditions, as a rule triggered by rainfall, sometimes in combination with human activities. Since the flysch rock mass is poorly permeable, the precipitation water infiltration and the groundwater level increase which are crucial for the landslide activation, are slow processes. Therefore, it should be expected, that longer continuous rainfall events are critical for landslide initiation, while short and intensive rainfall events play a greater role in the erosion processes.

The analyzed landslides occurred when the cumulative precipitation values range over $500 \mathrm{~mm}$ and up to $800 \mathrm{~mm}$. It is also evidenced that the maximum daily precipitation, does not have an exclusive significant influence on landslide initiation. Table 2 shows that the maximum daily rainfall corresponding to the three-month cumulative trigger is between $35 \%$ and $38 \%$ of the maximum daily rainfall registered at all events which exceeded triggering value. The records of 
rainfall in flysch areas show numerous examples with extreme daily rainfall and no instability occurrence, while the number of rainy days in this few month period can vary from $1 / 3$ to $2 / 3$ of the total days in the period. Established return periods for rainfall events that triggered landslides in the past, vary from 7 to 25 years. The variability of the results on different rain gauges indicate the need to associate the analysis with the precise local conditions, i.e. local rain gauge data. Since events with significant number of arid days were not excluded from the analysis, it can be assumed that elimination of such events would result in greater return periods. Separate events, which correspond to the minimum duration of the period without rain between two consecutive rainfall events should be determined in a future analysis.

The presented results suggest critical rainfall conditions corresponding to the increased landslide reactivation risk and need for the pre-alert measurements. Trends of this rainfall events could be considered as a temporal component of the landslide hazard assessment in the area. The accurate rate of the rainfall infiltration and groundwater level oscillation should be associated with the precipitation levels during the analyzed period.

\section{Acknowledgements}

We would like to acknowledge the University of Rijeka for support through the research Project "Analysis of the Rock Mass and Instability Phenomena Along the Karst-Flysch Contacts”.

\section{References}

[1] Fell, R., Corominas, J., Bonnard, C., Cascini, L., Leroi, E., Savage, W.Z. on behalf of the JTC-1 Joint Technical Committee on Landslides and Engineered Slopes (2008): Guidelines for landslide susceptibility, hazard and risk zoning for land use planning, Engineering Geology, 102, 85-98.

[2] Mihalić Arbanas, S., Krkač, M., Bernat, S., Arbanas, Ž.: Use of existing data in the City of Zagreb (Croatia, Europe) for the purpose of geo-planning, Proceedings „Advances in Underground Space Development “, (Zhou, Y., Cai, J., Sterling, R. (eds.), Singapore: Research Publishing, 2012, 465-477.
[3] Studer, B.: Remarques géognostiques sur quelques parties de la chaîne septentrionale des Alpes, Annales des Sciences Naturelles Paris, 11, 1827, 1-47.

[4] Benac, Č.: Dictionary of terms in applied geology and geological engineering, University of Rijeka, Faculty of Civil Engineering, 2013.

[5] Kuenen, Ph. H., Migliorini, C. I.: Turbidity currents as a cause of graded bedding, Journal of Geology, 58, 1950, 91-127.

[6] Flores, G.: Discussion in Beneo, E. Les resultants des etudes pour la recherché pétrolifére en Sicili, Proceedings of the 4th World Petroleum Cong. Rome Sec. 1/A\& Boll. Soc. Geol. Ital., 78, 1955, 1-26.

[7] Bouma, A. H.: Sedimentology of some Flysch Deposits, A Graphic Approach to Facies Interpretation, Elsevier, Amsterdam, 1962, 168.

[8] Esteban, M., Santanach, P. F.: Deslizamientos gravitacionales y olistostromas miocenos en el bajo Gaià y Campo de Tarragona, Acta Geologica Hispánica IX, 1974, 117-125.

[9] Mutti, E., Tinterri, R., Benevelli, G., DiBiase, D., Cavanna, G.: Deltaic, mixed and turbidite sedimentation of ancient foreland basins, In: Mutti, E., Steffens, G.S., Pirmez, C., Orlando, M., Roberts, D. (eds.), Turbidites: models and problems, Marine and Petroleum Geology 20, 2003, 733-755.

[10] Mutti, E., Bernoulli, E., Ricci Lucchi, F., Tinterri, R.: Turbidites and turbidity currents from Alpine "flysch" to the exploration of continental margins, Sedimentology, 56, 2009, 267-318.

[11] Arbanas, Ž., Benac, Č., Jardas, B.: Small landslides on the flysch of Istria, Proceedings of the 3rd Conference of Slovenian Geotechnical Society, Sloged, Ljubljana, 1, 1999, 81-88.

[12] Kendall, Ch.: SEPM Sequence Stratigraphy Web, http://sepmstrata.org/deepwater/ DeepwaterClasticArchitecture.html.

[13] Benac, Č.: Engineering - geological characteristics of the coastal belt and Rijeka Bay sea bed, Dissertation, University of Zagreb, Faculty of mining, geology and petroleum (in Croatian), 1994.

[14] Mlinar, Ž.: Station D-3: landslide Lupoglav, Guide book, 1. Geological congress, Vlahović, I., Velić, I. (eds.), Opatija, Croatia, 1995., 162171. 
[15] Arbanas, Ž., Benac, Č., Jurak, V.: Causes of debris flow formation in flysch area of North Istria, Croatia. Monitoring, Simulation, Prevention and Remediation of Dense and Debris Flows, Lorenzini, G., Brebbia, C. A., Emmanouloudis, D. E. (eds.), WIT Transaction on Ecology and the Environment, 90 (2006), 283-292.

[16] Arbanas, Ž., Dugonjić, S., Benac, Č.: Causes of small scale landslides in flysch deposits of Istria, Croatia, Proceedings of Second World Landslides Forum, Rome, 03-07th October, 2011, 221-226.

[17] Dugonjić Jovančević, S.: Landslide hazard assessment on flysch slopes, Dissertation, University of Rijeka, Faculty of Civil Engineering, 2013, 199.

[18] Dugonjić Jovančević, S., Arbanas, Ž.: Recent landslides on the Istrian Peninsula, Croatia, Natural Hazards, 62 (2012), 3: 1323-1338.

[19] Dugonjić Jovančević, S., Arbanas, Ž.: Influence of the runout potential on landslide-susceptible areas along the flysch-karst contact in Istria, Croatia, Natural Hazards, 85 (2017), 3; 13471362.

[20] Vivoda Prodan, M., Arbanas, Ž.: Weathering Influence on Properties of Siltstones from Istria, Croatia, Advances in Materials Science and Engineering, 2016 1-15.

[21] Vivoda Prodan, M., Mileusnić, M., Mihalić Arbanas, S., Arbanas, Ž.: Influence of weathering processes on the shear strength of siltstones from a flysch rock mass along the northern Adriatic coast of Croatia, Bulletin of Engineering Geology and the Environment, 76 (2017), 2, 695-711.

[22] Peranić, J., Arbanas, Ž., Cuomo, S., Maček, M.: Soil-Water Characteristic Curve of Residual Soil from a Flysch Rock Mass, Geofluids, $2018 \quad$ (2018). 1-15. 10.1155/2018/6297819

[23] Peranić, J.: Importance of Geotechnical CrossSection Unsaturated Zone for Landslide Occurrence in Flysch Deposits, Dissertation, University of Rijeka, Faculty of Civil Engineering, 2019.

[24] Marinčić, S.: Eocene flysch of Adriatic belt, Geological Almanac, Zagreb, 34: 27-38, 1981.

[25] Gil, E., Dlugosz, M.: Threshold values of rainfalls triggering selected deep-seated landslides in the Polish flysch Carpathians, Studia Geomorphologica Carpatho-Balcanica, 40 (2006), 21-43.
[26] Tosatti, G., Castaldini, D., Barbieri, M., D’Amato Avanzi, G., Giannecchini, R., Mandrone, G., Pellegrini, M., Perego, S., Puccinelli, A., Romeo, R. W., Tellini, C.: Additional Causes of Seismical Related Landslides in the Northern Apennines, Italy, Revistade Geomorfologie, 10:5-21, 2008.

[27] Polemio, M.: Rainfall and Senerchia Landslides, Southern Italy, Proceedings of the 2nd Pan American Symposium on Landslides, 2nd COBRAE, Rio De Janeiro, Brasil, 175184, 1997.

[28] Logar, J., Fifer Bizjak, K., Kočevar, M., Mikoš, M., Ribičič, M., Majes, B.: History and present state of the Slano Blato Landslide, Natural Hazards and Earth System Science, 5 (2005), 447-457.

[29] Klimeš, J., Baron, I., Panek, T., Kosačik, T., Burda, J., Kresta, F., Hradecky, J.: Investigation of recent catastrophic landslides in the flysch belt of Outer Western Carpathians (Czech Republic): progress towards better hazard assessment, Natural Hazards and Earth System Science, 9 (2009), 119-128.

[30] Velić, I., Vlahović, I.: Geologic map of Republic Croatia 1:300 000, Croatian Geological Survey, Zagreb (in Croatian), 2009.

[31] Korbar, T.: Orogenic evolution of the External Dinarides in the NE Adriatic region: a model constrained by tectonostratigraphy of Upper Cretaceous to Paleogene carbonates, EarthScience Reviews, 96 (2009), 296-312.

[32] Polšak, A.: Geologic map of Republic Croatia 1:100.000, sheet Pula, Institute for geological research, Zagreb, Federal Geological Survey, Beograd, 1967.

[33] Pleničar, M., Polšak, A., Šikić, D.: Geologic map of Republic Croatia 1:100.000, sheet Trst, Institute for geological research, Zagreb, Federal Geological Survey, Beograd, 1969.

[34] Polšak, A., Šikić, D.: Geologic map of Republic Croatia 1:100.000, sheet Rovinj, Institute for geological research, Zagreb, Federal Geological Survey, Beograd, 1969.

[35] Šikić, D., Polšak, A., Magaš, N.: Geologic map of Republic Croatia 1:100 000, sheet Labin, Institute for geological research, Zagreb, Federal Geological Survey, Beograd, 1969.

[36] Šikić, D., Pleničar, M., Šparica, M.: Geologic map of Republic Croatia 1:100 000, sheet Ilirska Bistrica, Federal Geological Survey, Beograd, 1972. 
[37] Bergant, S., Tišljar, J., Šparica, M.: Eocen carbonates and flysch deposits of the Pazin basin, 22nd IAS Meeting of Sedimentology, Opatija, Field trip guidebook, 2003.

[38] Jevđević, V.: Probability and statistics in hydrology, Sarajevo, PZ for research of karst issues in water management, 1977.
[39] Salas, J. D., Deller, J. W., Yevjevich, V., Lane, W. L.: Applied modelling of hydrologic time series, Water Resources Publications, Littletown, 1990. 